\title{
Развитие туризма на территориях национальных парков Казахстана
}

\author{
Ассем Сейтимова ${ }^{1}$, Ардак Бейсембинова ${ }^{1}$, Ернур Баекеев $^{2}$ \\ ${ }^{1}$ Казахский Наџиональный Университет имени Аль-Фараби, Алматы, Казахстан \\ ${ }^{2}$ Филиал AO «POSCO International Corporation» Алматы, Казахстан
}

\begin{abstract}
АННОТАЦИЯ
В статье изучены перспективы для развития туристской деятельности на особо охраняемых природных территориях, в частности государственных национальных природных парков в Республике Казахстан. Определены сдерживающие факторы, слабые стороны для развития туризма на территориях нацпарков. Даны пути решения проблем и сдерживающих факторов в условиях пандемии для переориентации выездного туристского потока на развитие внутреннего туризма. Проведен анализ самых популярных туристских направлений среди нацпарков.
\end{abstract}

Ключевые слова: национальные природные парки, туризм, пандемия, государство

\section{ВВЕДЕНИЕ}

Актуальность исследования заключается в том, что 2020 год, год пандемии стала переломным для многих сфер народного хозяйства, туристская индустрия не стала исключением. В связи с закрытием границ между странами, путешествующих по миру, резко сократилось.

В условиях пандемии COVID-19 необходимо переориентация выездного туристского потока на развитие внутреннего туризма, соответственно необходимо быть готовыми удовлетворить потребности иностранных и внутренних туристов на территории Республики Казахстан (РК).

Казахстан может удивить туристов богатыми природными ресурсами, полезными ископаемыми, горными и рекреационными зонами, национальными природными парками.

Государственные национальные природные парки имеют важное значение для сохранения и устойчивого использования биологических разнообразий в РК.

На сегодняшний день Правительство страны уделяет большое значение формированию эффективного развития природных парков, а также развитию туристской деятельности на территории нацпарков.

Авторами показано, что в условиях пандемии развитие туристской деятельности на территориях нацпарков имеет важное значения для позитивного представления об этих объектах. Следует признать, что имеются различные проблемы с развитием туристской деятельности на территориях нацпарков, самым главным из них является создание инфраструктуры, а также развитие санитарно-гигиенических узлов на основных трассах республиканского, местного значения и трассах, ведущих к туристским достопримечательностям, что в настоящее время является актуальной задачей.

Проблема исследования. Несмотря на то, что страна имеет большой потенциал, Казахстан еще не готов удовлетворять потребности зарубежных и отечественных туристов по ряду причин. Казахстан занял 80-место в совокупном рейтинге конкурентоспособности туризма и путешествий среди 140 стран мира в 2019 году, а в части туристской инфраструктуры 89-место (Calderwood, Soshkin, 2019). 
Цель исследования. Показать и обосновать возможности развития туризма на территориях национальных парков Казахстана.

Задачи исследования:

1. Провести анализ перспективных национальных парков в РК.

2. Определить сдерживающие факторы развития туризма на территориях национальных парков.

3. Найти инструмент, который можно применить для развития туризма на территориях национальных парков.

\section{МЕТОДОЛОГИЯ ИССЛЕДОВАНИЯ}

Публикации отечественных и зарубежных исследователей, интернет ресурсы стали основой научного метода анализа, теоретических и методологических понятий связанные с проблемами развития туризма на территориях национальных природных парков.

Данные для исследования взяты из статистических данных, в частности, базы из официальных органов статистики, для определения мониторинга потока туристов.

Нормативной базой исследования послужили действующие нормативно-правовые акты и др.

\section{РЕЗУЛЬТАТЫ ИССЛЕДОВАНИЯ И ДИСКУСИЯ}

В соответствии с Законом РК «Об особо охраняемых природных территориях» государственный национальный природный парк - это природоохранные территории, которые характеризуются природными комплексами и объектами, имеющий ценность экологического, исторического, эстетического характера, рассчитанный для использования просветительских, культурно-познавательных целях, также для туристской деятельности и отдыха (Закон РК от 07.07.2006 г).

Основной целью национальных парков является обеспечение безопасности уникальности дикой природы, при этом дать возможность посетителям насладиться этой дикой природы.

Суммарное количество посетителей нацпарков на территории Казахстана за 2019 год составило приблизительно 1380000 человек, относительно мировых лидеров, то это очень мало. Краткое описание каждого национального парка приведена в таблице 1.

Основными задачами нацпарков являются:

1. Обеспечение сохранности памятникам природы, уникальным и эталонным природным участкам, и объектам природы, природным и историко-культурным наследиям.

2. Предоставить экологическое образованность.

3. Формирование научной методологии спасения биологических разнообразии.

4. Воссоздание испорченных памятников природы, природных и историко-культурных наследий.

5. Контролирование пользования объектов и территорий национальных природных парков. 


\section{Таблица 1. Описание национального парка на территории Казахстана}

(Составлен автором на основании официальных источников)

\begin{tabular}{|l|l|l|l|l|}
\hline № & Название ГНПП & Область & Площадь, га & $\begin{array}{l}\text { Кол. посетителей } \mathbf{3 a} \\
\mathbf{2 0 1 9} \text { год* }\end{array}$ \\
\hline 1 & Кокшетау & Акмолинская & 182076 & 64 тыс. \\
\hline 2 & Бурабай & Акмолинская & 129299 & 683 тыс. \\
\hline 3 & Иле-Алатауский & Алматинская, г. Алматы & $186400 / 12219$ & 288 тыс. \\
\hline 4 & Чарынский & Алматинская & 127050 & 20 тыс. \\
\hline 5 & Алтын-Эмель & Алматинская & 307653,35 & 19 тыс. \\
\hline 6 & Көлсай көлдері & Алматинская & 161045 & 88 тыс. \\
\hline 7 & Жонгар-Алатауский & Алматинская & 356022 & 1,5 тыс. \\
\hline 8 & Катон-Карагайский & Восточно-Казахстанская & 643477 & 4,5 тыс. \\
\hline 9 & Тарбагатай & Восточно-Казахстанская & 143550,5 & - \\
\hline 10 & Каркаралинский & Карагандинская & 112120 & 42 тыс. \\
\hline 11 & Буйратау & Карагандинская & 88968 & 2 тыс. \\
\hline 12 & Баянаульский & Павлодарская & 68452,8 & 130 тыс. \\
\hline 13 & Сайрам-Угамский & Туркестанская & 149037,1 & 33 тыс. \\
\hline
\end{tabular}

Одним из первых национальных парков, который появился в нашей стране является Баянаульский парк, основанный в 1985 году. Если сравнивать с первым национальным парком в мире, то это было в США в 1872г. Йеллоустонский.

Стоит отметить, что национальный парк Алтын Эмель занял 23-место в рейтинге лучших нацпарков мира 2020 года, при этом число посетителей составило всего лишь 19 тысяч в 2019 году. Если сравнить площадь, то она в 4 раза больше Гонконга (100 Best National Parks in the World, 2021).

В период пандемии COVID-2019 необходимость закрытия границ между странами повлияла на передвижение туристов, соответственно туристская деятельность потерпела резкий спад. Люди, чтобы отдохнуть, стали путешествовать внутри своей страны, узнавать и посещать новые места отечественных объектов. В связи с этим необходимо развивать внутренний туризм.

Из-за резких снижений поездок между странами в 2020 году индустрия туризма потеряла около 4,5 триллиона долларов США экспортных доходов от международного туризма (Industry update, 2021).

Развитие туристской индустрии имеет ряд преимуществ:

1. Высокий экономический рост. Туристская индустрия считается одним из самых высокорентабельных и быстро двигающихся сфер народного хозяйства.

2. Высокая рентабельность.

3. Появление рабочих мест.

4. Пополнение регионального бюджета

Следовательно, развитие туристской индустрии на территориях нацпарков поспособствует разнообразию хозяйственной деятельности, также сократит безработицу. 


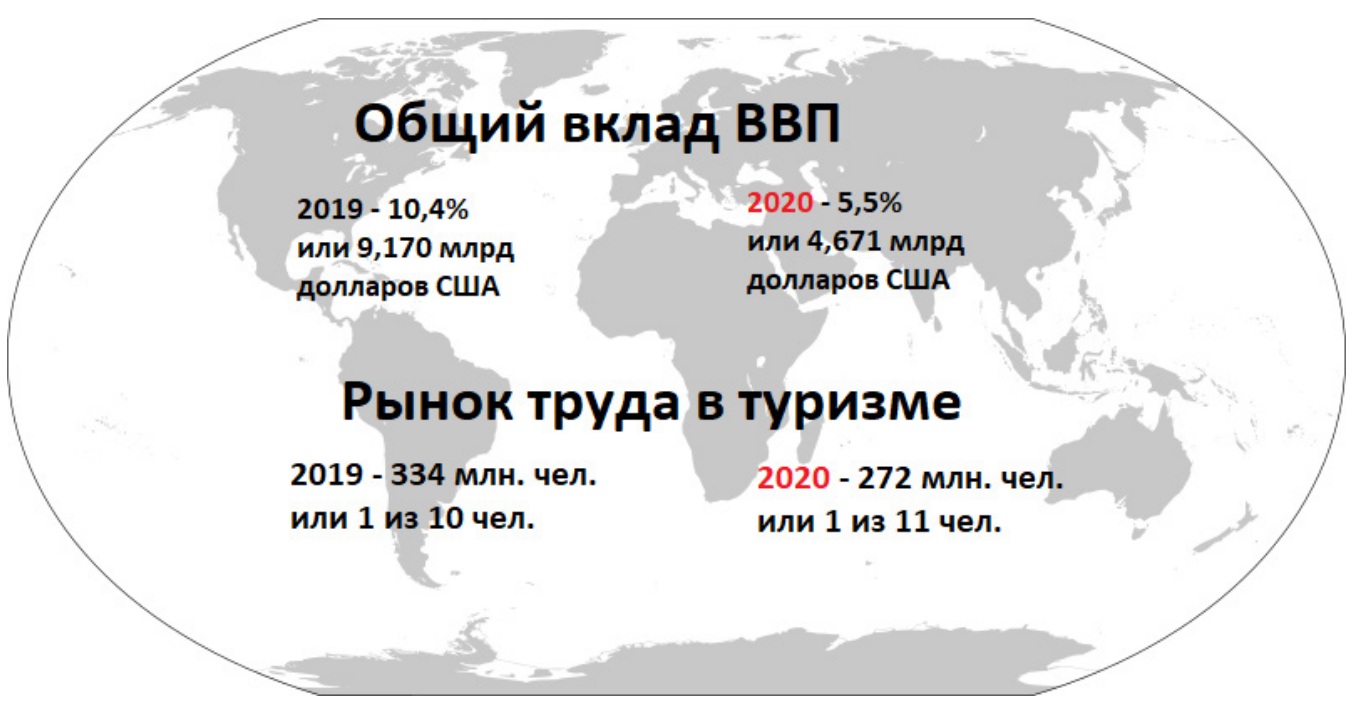

Рисунок 1. Экономический эффект от пандемии COVID-19 (Industry update, 2021)

Казахстан имеет большой потенциал для развития туристской деятельности на территориях нацпарков, но пока, не может похвастаться большим потоком туристов по ряду причин.

Препятствующие факторы для развития туризма на территориях нацпарков:

- отсутствие необходимой инфраструктуры (оборудованные туристские тропы, кемпинги, глэмпинги, современные санитарные кабинки и др.)

- слабая финансовая поддержка мероприятий, развивающие туристскую индустрию и рекреационную деятельность.

- климатические условия на территории Казахстана.

- отсутствие квалифицированных кадров.

- слабая нормативная база в сфере экотуристской индустрии.

Все вышеуказанные факторы препятствуют большому потоку туристов на территориях нацпарков, развитию туристской индустрии.

Для того, чтобы избавиться от препятствующих факторов, которые приведены необходимо:

Во-первых, активное участие государства в реализации проектов, связанных с туристской деятельностью.

Во-вторых, формирование эффективного управленческого процесса на территориях нацпарков, то есть это контроль за приемом и числом туристов, информационные процессы, поддержка защищенности туристов, услуги гидов-переводчиков, и в целом благоприятные условия на территории.

В-третьих, одним из эффективных инструментов со сложившейся ситуацией является использование механизма ГЧП.

Существуют различные интерпретации механизма ГЧП в самом распространенном виде под ГЧП понимается сотрудничество и объединение общих сил государства и частного сектора для реализации общих задач в виде различных проектов (Багирян, 2016).

1 апреля 2021 года были внесены изменения и дополнения в Закон РК «Об особо охраняемых природных территориях», в частности в статье 46 говорится о том, что частному сектору разрешена туристская и рекреационная деятельность на территориях государственных 


\section{национальных парках сроком в краткосрочном периоде до 5 лет, в долгосрочном периоде до 25 лет в рамках ГЧП.}

Если частное предпринимательство будет соблюдать все правила и требования, то это уникальная возможность увеличить туристский поток, улучшить условия, которые препятствуют развитию туризма.

\section{ВЫВОДЫ}

Казахстану должно прийти осознание того, что страна обладает огромным природным богатством, это широколиственные леса, озера, большое количество рек, великорослые горы, бескрайная степь, вдобавок имеются удивительные и необычные растения и животные. Необходимо уметь оценивать и использовать возможности нашей страны и постараться эффективно пользоваться ресурсами страны. Это может позволить росту въездного туристского потока, увеличению достатка региона, росту занятости населения, экономической прибыли региона и страны в целом.

Государственные национальные парки необходимы для соблюдения благоприятной обстановки для жизнедеятельности людей. Соблюдение здоровой среды в нацпарках дают возможность показать развитие общества в гармонии с природой.

Территория национального парка - это то место, где человек может познакомиться с ценностями дикой природы, понять духовные ценности своей страны и всего человечества.

Таким образом проведя анализ государственных нацпарков на территории Казахстана, целесообразно максимально использовать прекрасные пространства нацпарков, для развития туристской деятельности. Для этого в первую очередь необходимо качественная инфраструктура, помощь государства и частного инвестора, соблюдение всех правил и требований как со стороны посетителей, так и со стороны организатора туристского объекта.

\section{ЛИТЕРАТУРА}

1. 100 Best National Parks in the World. (2021). TourScanner,Электронный ресурс. Код доступа https://tourscanner. com/blog/best-national-parks-in-the-world/

2. Calderwood, L. U., \& Soshkin, M. (2019). The travel and tourism competitiveness report 2019. World Economic Forum. Электронный ресурс. Код доступа http://www3.weforum.org/docs/WEF_TTCR_2019.pdf

3. Industry update. (2021). WTTC research reveals global Travel \& Tourism sector suffered a loss of almost US\$4.5 trillion in 2020 due to the impact of COVID-19. Официальный сайт Всемирного совета по туризму и путешествиям. Код доступа https://wttc.org/News-Article/Global-TandT-sector-suffered-a-loss-of-almost-US4trillion-in-2020

4. Багирян, В. А. (2016). Государственно-частное партнерство в туризме как инструмент защиты национальных интересов государства. Финансовые исследования, 2 (51), 62-68.

5. Закон РК «Об ООПТ» от 07.01.2006 с изменениями и дополнениями от 01.04.2021. [Дата обращения: 20.03.2021] Код доступа https://adilet.zan.kz/rus/docs/Z060000175_\#z24

6. Перечень особо охраняемых природных территориях республиканского значения, утвержденный постановлением Правительства РК от 26.09.2017 №593, с изменениями и дополнениями от 29.07.2020. Код доступа https://adilet.zan.kz/rus/docs/P1700000593

7. Созиева, 3. И. (2009). Развитие туристического комплекса в национальном парке как фактор развития региона. Туристско-рекреационные зоны, 35, 66-71. 


\title{
Tourism development in national parks of Kazakhstan
}

\author{
Assem Seitimova', Ardak Beysembinova ${ }^{1}$, Yernur Baekeyev ${ }^{2}$ \\ ${ }^{1}$ Al-Farabi Kazakh National University, Almaty, Kazakhstan \\ ${ }^{2}$ Almaty Branch of POSCO International Corporation, Almaty, Kazakhstan
}

\begin{abstract}
Relevance. The relevance of the study lies in the fact that 2020, the year of the pandemic, became a turning point for many areas of the national economy, and the tourism industry was no exception. Due to the closure of borders between countries, International Tourism was dropped dramatically. In the context of the COVID-19 pandemic, it is necessary to refocus on growing outbound tourist flow to the development of domestic tourism; accordingly, it is necessary to be ready to meet the needs of foreign and domestic tourists in the territory of the Republic of Kazakhstan.

Kazakhstan can surprise tourists with its rich natural resources, minerals, mountainous and recreational areas, and natural parks as well. State national parks are important for the conservation and sustainable use of biological diversity in the Republic of Kazakhstan. These days the Government is paying great attention to the formation of effective development of natural parks, as well as the development of tourist activities in national parks.

The authors show that in the context of a pandemic, the development of tourist activities in national parks is important for a positive image of these objects. It should be recognized that there are various problems with the development of tourist activities in national parks, the most important of which is the creation of infrastructure, as well as the development of sanitary and hygienic units on the main roads of republican, local significance and highways leading to tourist attractions.

Research problem. Despite the fact that the country has great potential, Kazakhstan is not ready to meet the needs of foreign and domestic tourists due to some reasons. Kazakhstan took 80th place in the cumulative rating of the competitiveness of tourism and travel among 140 countries of the world in 2019, and in terms of tourism infrastructure, 89th place (World Economic Forum, 2020).
\end{abstract}

Purpose of the study. Show and substantiate the possibilities for Tourism development in national parks of Kazakhstan.

Research methods. Publications of domestic and foreign researchers, Internet resources have become the basis of the scientific method of analysis, theoretical and methodological concepts associated with the problems of Tourism Development in natural parks.

The data for the study were taken from statistical data, in particular, from the database from the Official Statistics Authorities, to determine the monitoring of the flow of tourists. The regulatory framework for the study was the current regulatory legal acts, etc.

Conclusions. Kazakhstan should realize that the country has a huge natural wealth, these are broad-leaved forests, lakes, a large number of rivers, great mountains, endless steppe, in addition, there are amazing and unusual plants and animals. It is necessary to be able to assess and use the capabilities of the country and try to effectively use the country's resources. This can allow an increase in inbound tourist flow, an increase in the region's prosperity, an increase in employment, the economic profit of the region and the country as a whole. National parks are necessary to maintain a favorable environment for the life of people. Observance of a healthy environment in national parks provides an opportunity to show the development of society in harmony with nature. The territory of the national park is the place where a person can get acquainted with the values of wild nature, understand the spiritual values of his or her country and all mankind. Thus, after analyzing the state national parks of Kazakhstan, it is advisable to make the most of the beautiful spaces of the national park for the development of tourist activities. To do this, first of all, we need high-quality infrastructure, assistance from the Public and Private partners, compliance with all rules and requirements both on the part of visitors and on the part of the organizer of the tourist facility.

Key words: Natural parks, Tourism, Pandemic, State 